\title{
Growth, Challenges and Issues related to Micro, Small and Medium Enterprises (MSMEs) in Jammu and Kashmir
}

\section{Waseem Hamid*}

Government Hamidiya Arts and Commerce Degree College, Budhwara, Bhopal, Madhya Pradesh, India

*Corresponding author: Waseem Hamid, Research Scholar, Government Hamidiya Arts and Commerce Degree College, Budhwara, Bhopal, Madhya Pradesh, India, Tel: +0755 266 0447; E-mail: rajawaseem118@gmail.com

Received date: November 04, 2017; Accepted date: November 21, 2017; Published date: November 28, 2017

Copyright: () 2017 Hamid W. This is an open-access article distributed under the terms of the Creative Commons Attribution License, which permits unrestricted use, distribution, and reproduction in any medium, provided the original author and source are credited.

\begin{abstract}
Micro, Small and Medium Enterprises (MSMEs) have played an imperative role in the economic activities of advanced industrialized countries like Great Britain Germany, Japan, and the United States of America. In developing countries like India, these industries or Enterprises have an enormous importance due to its high level employment potential with low capital cost. MSMEs are also supporting in industrialization of rural backward areas. This sector is also called the nursery of entrepreneurship. This study is regarding Jammu and Kashmir (J\&K) of the India, an industrial backward state of India. In J\&K large scale industries are present in small numbers; only MSMEs/SSI units are growing after a long gap of disturbance. From last two decades MSMEs/SSI have been growing in a satisfactory pace as per circumstances of the state. However these enterprises are facing different hurdles in overall growth and development like poor infrastructure, shortage of electricity, political instability and financial problems. Government is outlining different policies and schemes for the growth of this sector but unfortunately failing to complete their objectives. This paper will draw attention towards Growth, Challenges and Issues related to Micro, Small and Medium Enterprises (MSMEs) of J\&K.
\end{abstract}

Keywords: MSMEs; Growth; Employment; Political instability; Challenges

\section{Introduction}

Industrialization is a key to economic development of a country [1] Micro, Small and Medium enterprises (MSMEs) have played an imperative role in the economic activities of highly developed industrialized countries like Japan, Germany, Great Britain and the United States of America. In developing economy like India, where agriculture is main source of livelihood, poverty and unemployment is prevailing all over. In order to eradicate poverty and unemployment, manufacturing sectors has to develop obligatory. Both in developed and developing countries, Small scale industries or micro, small and medium enterprises have been documented as noteworthy contributors in satisfying various socio-economic objectives such as higher growth of employment, promotion of exports and fostering entrepreneurship. These enterprises are nursery for entrepreneurship and seedbed for future growth. The MSMEs sector is a key pillar of an Indian economy.

Jammu and Kashmir is located in northern of India, covered with Himalayan Mountains. The political, climatic and geographical conditions of the state are absolutely different from other states. Unfortunately, $\mathrm{J} \& \mathrm{~K}$ is not able to attract investment in secondary sector and remained industrial backward state. The political instability and poor infrastructure are key causes of industrial backwardness. The armed conflict has not only taken the precious lives but also it has shaken the economy of the state from its roots [2]. The educated unemployment level of the state is growing day by day, due to backwardness of manufacturing sector. Large scale industries are absent in state [3]. Only micro, small and medium enterprises are growing with the efforts of centre and state governments. The number of small scale industrial units as on November, 2014 registered with the State Directorate of Industries and Commerce is more than fifty seven thousands providing employment opportunities to 2.77 lakh people. The opportunities for MSMEs are adequate in the state, the availability of raw material and cultural conditions are supporting those enterprises. But the blockages in path of industrialization like climatic conditions, poor infrastructure, political instability, shortage of raw material, lack of skilled labour, financial problems etc. are main hurdles in the swiftness of industrial sector in state.

\section{Definition of micro, small and medium enterprises}

The definition of small scale industries varies from country to country or varies in same country from time to time. In India, new classification of small scale industries was done on the basis of investment. According to latest definition of small scale industries by MSME Development Act, 2006 under the section of 7, small scale industries are divided into three enterprises; according investment like Micro, Small and Medium enterprises. The new nomenclature of small scale industries is given below (Table 1).

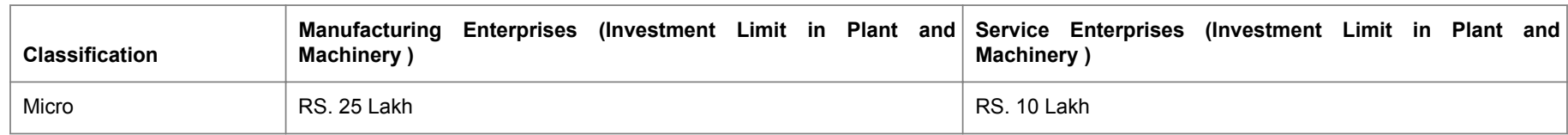


Citation: Hamid W (2017) Growth, Challenges and Issues related to Micro, Small and Medium Enterprises (MSMEs) in Jammu and Kashmir.

Page 2 of 6

\begin{tabular}{|l|l|l|}
\hline Small & RS. 5 Crore & RS. 2 Crore \\
\hline Medium & RS. 10 Crore & RS. 5 Crore \\
\hline Source: Ministry of Micro, Small and Medium Enterprises. & \\
\hline
\end{tabular}

Table 1: New nomenclature of small scale industries under MSMED Act 2006.

\section{Objectives of the Study}

- To examine the growth and employment of MSMEs in the state.

- To study the opportunities for MSMEs in the state.

- To find out the challenges of MSMEs in the state.

\section{Review of Literature}

They have highlighted that the Micro, Small and Medium enterprises are playing predominant role in Indian economy in terms of employment, production, exports and fostering entrepreneurship in a nation.

Sharma et al. [4] have reported that MSMEs are the back bone of the Indian manufacturing sector and have been engine of economic growth in India. MSMEs as compare with big enterprises are providing employment opportunities with minimum capital cost.

Their study found that the MSMEs are facing different problems like sub-optional sale of operation, technological obsolescence, supply chain insufficiencies, increasing domestic and global completion, Fund shortages, Change in manufacturing strategies and turbulent and uncertain market scenario.

Bhat and Malik [5] have concluded their study with-that industrial sector plays an important role in economic development and employment generation of an economy. They also highlighted that industrial sector is major contributor to the gross national product (GNP) after services sector in India. Suggestion was provided in their study that development of Micro, small and medium enterprises (MSMES) are necessary for the Jammu and Kashmir economy in terms of output, employment generation, foreign exchange earnings in national income.

Mohandass [6] in his study revealed that Micro, Small and Medium enterprises are providing maximum opportunities for both selfemployment and job outside agricultural sector.

Onukwuli et al. [7] have suggested that with the growth and development of MSMEs the poverty will automatically remove.

Kumar and Kamal [8] have suggested that latest technology (Emarketing or web marketing) may help small manufacturer to connect with large number of buyer. They also highlighted that small industries need to improve their distribution channels for maximum coverage of the buyer.

\section{Research Methodology}

Research is a well-planned, well designed and systematic study of an identified problem. It involves, collection of data and analysis it to discover of new facts.

\section{Data collection}

Both primary and secondary sources of data were used in the present study. Primary data was collected through simple random sampling technique from a sample of 250 MSMEs respondents by a questionnaire from Jammu and Kashmir. Secondary source of data was collected from different published sources of departments like Ministry of Micro, Small and Medium Enterprises, and Directorate of Economic Planning and Statistics, J\&K. The other relevant data was collected from journals, libraries and websites.

\section{Methods}

\section{Henry Garrett's ranking technique}

Henry Garrett's ranking technique was used to rank the problems faced by the MSMEs enterprises in Jammu and Kashmir. In this method, the respondents were asked to rank the given problems according to the degree. The order of merit given by the respondents was converted into ranks by using the following formula.

Percentage Position $=\frac{100(R i j-0.5)}{N j}$

Here,

Rij=Rank given for $\mathrm{i}_{\mathrm{th}}$ item by $\mathrm{j}_{\mathrm{th}}$ individual;

$N j=$ Number of items ranked by $\mathrm{j}_{\text {th }}$ individual.

The percentage position of each rank was converted into scores according by Henry Garrett table. After that, for each factor, the scores of individual respondents were added together and divided by the total number of respondents for whom the scores were added. These mean scores for all the factors were set in order of ranks and conclusion were drawn.

\section{Growth of micro, small and medium enterprises in Jammu and Kashmir}

Industrialization plays a significant role in employment creation of any economy. The Jammu and Kashmir State is on the path of Industrializations, large-scale and heavy industries are not present in an acceptable statistics; due to political instability, poor infrastructure and climatic disadvantages. Only Micro, Small and Medium enterprises are growing in a state. The availability of raw material, cultural and climatic conditions is supporting those enterprises in growth. Prospect and opportunities in this sector is dazzling; if proper attention will divert towards these enterprises. Small scale industrial units of the state are manufacturing food products, beverages, slick, bricks, plastic products etc. MSMEs are growing in state; at the end of 2014 total number of MSMEs was 57193 and providing employment to 277653 individuals (figure released by Directorate, Economic Planning and Statistics of J\&K). For immediate growth of MSMEs in state, registration procedure was simplified. District Industries Centre (DIC) has been set up in each district of the state, to provide all services to 
Citation: Hamid W (2017) Growth, Challenges and Issues related to Micro, Small and Medium Enterprises (MSMEs) in Jammu and Kashmir.

Page 3 of 6

the entrepreneurs under one roof. The Jammu and Kashmir entrepreneurship development institute in a valley is boosting, helping and guiding educated youth and diverting their attention towards manufacturing sector. Growth and employment of MSMEs is shown in a table given table.

\begin{tabular}{|l|l|l|l|l|}
\hline Year & No. of SSI/MSME Units & Growth rate & No. of Employments & Growth rate \\
\hline $2000-2001$ & 42808 & - & 187399 & - \\
\hline $2001-2002$ & 43689 & 2.05 & 193285 & 3.14 \\
\hline $2002-2003$ & 44701 & 2.31 & 198238 & 2.56 \\
\hline $2003-2004$ & 45672 & 2.17 & 203328 & 2.56 \\
\hline $2004-2005$ & 46818 & 2.5 & 209322 & 2.94 \\
\hline $2005-2006$ & 48224 & 3 & 219127 & 4.68 \\
\hline $2006-2007$ & 49426 & 2.49 & 225963 & 3.11 \\
\hline $2007-2008$ & 50470 & 2.11 & 232915 & 3.07 \\
\hline $2008-2009$ & 51441 & 1.92 & 238281 & 2.03 \\
\hline $2009-2010$ & 52629 & 2.3 & 245774 & 3.06 \\
\hline $2010-2011$ & 53544 & 1.73 & 251551 & 2.35 \\
\hline $2011-2012$ & 54714 & 2.18 & 260393 & 3.51 \\
\hline $2012-2013$ & 55742 & 1.87 & 267194 & 2.61 \\
\hline $2013-2014$ & 56660 & 1.64 & 274011 & 2.55 \\
\hline Source: Digest of Statistics $2013-14$, Directorate of Industries \& Commerce Kashmir/Jammu. & & \\
\hline
\end{tabular}

Table 2: Growth and Employment of SSI/ MSMEs units in Jammu and Kashmir.

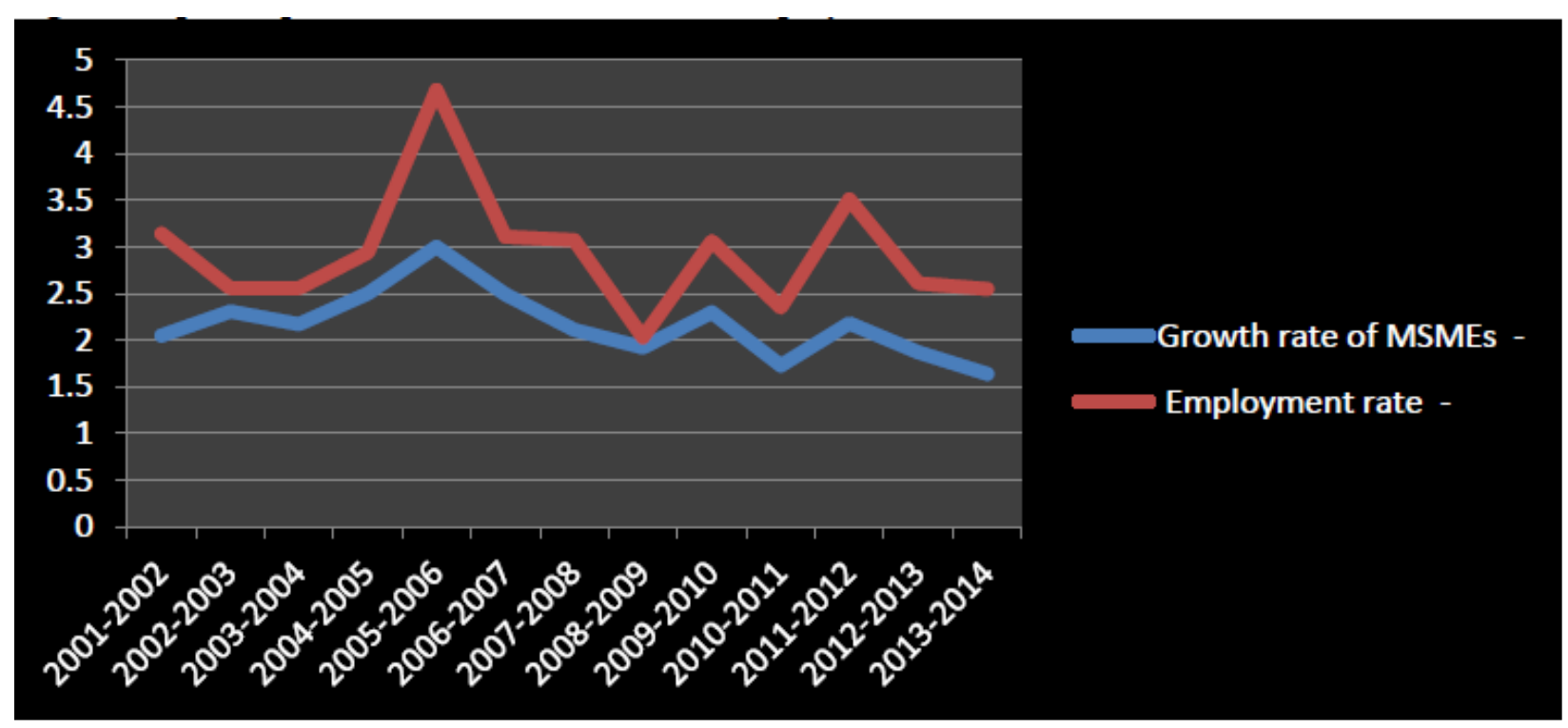

Figure 1: Graphical presentation of Growth and Employment rate of MSMEs in J\&K. Source: Digest of Statistics 2013-14, Directorate of Industries \& Commerce Kashmir/Jammu.

Table 2 and Figure 1 are showing the average growth and employment rate of MSMEs from 2001-02 to 2013-14. The above figure clearly depicts that the growth of MSMEs and employment is rising from 2004 to 2006 and after that growth rate of both is declining. 
Citation: Hamid W (2017) Growth, Challenges and Issues related to Micro, Small and Medium Enterprises (MSMEs) in Jammu and Kashmir.

Page 4 of 6

\section{Opportunities for MSMEs in Jammu and Kashmir}

Jammu and Kashmir is bestowed by the Allah with distinctive natural resources and fruits. The State of Jammu and Kashmir is very rich in Agro, Forest, Horticulture and Live Stock resources. There is plentiful availability of resources, which are quite suitable for setting up of different types of small scale industrial units in the area of Food Processing, Sports Goods, Leather Goods, Engineering Products and units based on medical Plants and herbs etc. The climatic condition of the state is very favorable for Electronics. Some other key opportunities for MAMEs are discussed below.

- Jammu and Kashmir has border connectivity with different countries like Pakistan and china. If the old trade links will restore again and new channels will open, positively benefited for the industrial sector of the state. The transportation cost will minimize, products of MSMEs can compete easily in international markets.

- Handicraft and sericulture industrial units have a great prospect in valley, due to availability of abundant raw material

- The availability of fruits in a good quality and quantity offers opportunity for food processing units.

- Wool and Khadi industries have opportunities in rural and forest areas of valley. Sheep farming is main occupation of those areas; availability of cheap raw material is obvious.

- Small scale Cricket bat manufacturing units have a prospect, due to availability of raw materials and demand from tourists.

- Dry fruit packing units have an opportunity in state.

- Growth of MSMEs can minimize the migration of skilled labours from J\&K to other states; State gross domestic production can increase (SGDP).
- Kangri (Fire Pot) makers have Opportunities, due to cultural and climatic advantages.

\section{Challenges of micro, small and medium enterprises in J\&K}

Each sector of an economy has dissimilar challenge in growth and development, same case with the industrial sector. Jammu and Kashmir is state, where challenges of all sectors are totally different from other states of nation like Political instability, unique climatic and geographical conditions. From the above cited conditions, it is undoubtedly understandable that large scale industries cannot survive in state, result is same. Small enterprises are backbone of industrial sector of state. But regrettably this sector is facing different problems in day-to-day operations of production and marketing. Poor infrastructure and limited sources of financial amenities are major problems of state. From last two and half decades Jammu and Kashmir has been under the political turmoil, impacted economy of state [2]. Even basic infrastructure facilities like power supply, road and communication system linger underdeveloped due to political instability [9]. In order to reach the ground level situation, simple random sampling technique was used; 250 MSMEs was selected from state. Through questionnaire the magnitude of different problems was identified by Garrett's ranking technique [10]. In this method, the respondents were asked to rank the given problem according to the magnitude of the problem. The order of merit given by the respondents was converted into ranks by using the Garrett's formula. The problems faced by MSMES according ranks are given below with the help of table (Figure 2).

\begin{tabular}{|c|c|c|c|c|}
\hline S. No. & Problems & Total scores & Average scores & Garrett's rank \\
\hline 1 & Marketing & 13234 & 52.93 & $\mathrm{VI}$ \\
\hline 2 & Power shortage & 15722 & 62.88 & III \\
\hline 3 & Raw material & 14260 & 57.04 & v \\
\hline 4 & Financial & 14960 & 59.84 & IV \\
\hline 5 & Infrastructure & 17562 & 70.24 & 1 \\
\hline 6 & Political instability & 16573 & 66.29 & $\|$ \\
\hline 7 & Climate & 12232 & 48.92 & VII \\
\hline 8 & Other & 11645 & 46.58 & VIII \\
\hline
\end{tabular}

Table 3: Degree of Problems faced by MSMEs of Jammu and Kashmir represented by Garret's rank technique. 
Citation: Hamid W (2017) Growth, Challenges and Issues related to Micro, Small and Medium Enterprises (MSMEs) in Jammu and Kashmir. Bus Eco J 8: 328. doi:10.4172/2151-6219.1000328

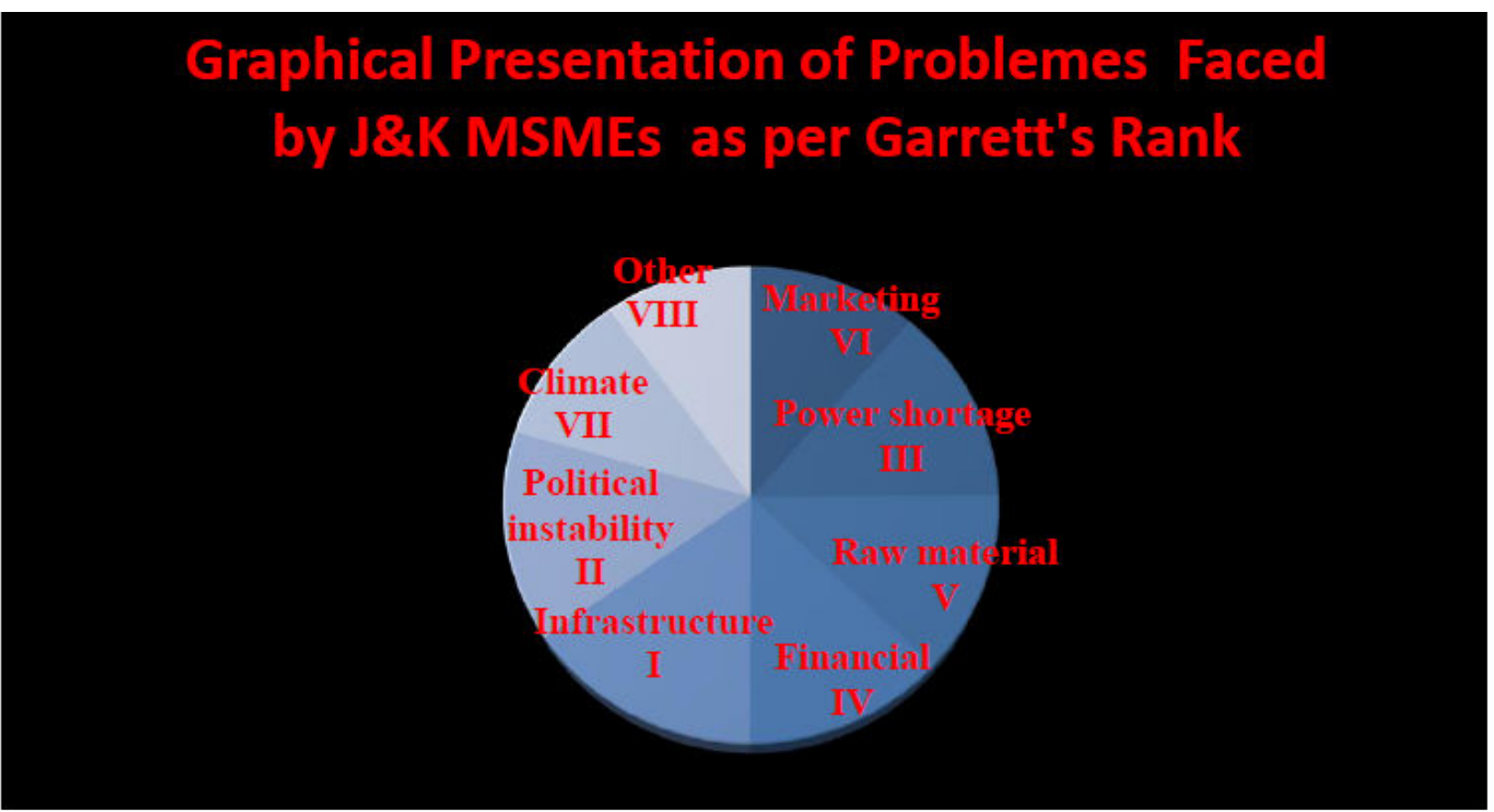

Figure 2: Graphical representation of problems faced by MSMEs. Source: Field Survey.

Table 3 representing the problems faced by MSMEs enterprise according their ranks by Garrett's rank technique [11-13]. The infrastructure has maximum average scores (70.24), ranked first (I) problem and political instability has 66.29 average scores; ranked second problem (II). The other problems like power shortage ranks third (III) with 62.88 average scores, financial problem has 59.84 average scores and ranks at forth (IV), raw material problem has 57.04 average scores and ranked at fifth (V), marketing problem has 52.93 average scores and ranked at sixth (VI), climate problem has 48.92 average scores and ranked at seventh (VII) and other problems has 46.58 average scores and ranked at eighth (VIII).

\section{Result and Conclusion}

Micro, small and medium enterprises have emerged as the engine of economic growth and equitable distribution of national income. Jammu and Kashmir as an industrial backward state of India, only micro, small and medium enterprises are growing after a long gap of disturbance with the efforts of centre and state government. The attention of young educated generation is diverting toward manufacturing sector by the firm efforts of Jammu and Kashmir entrepreneurship development institute (JKEDI). J\&K is attempting diligently to create investment atmosphere, due to political instability all is fruitless. There is a need to eradicate all the stumbling blocks coming in the way of industrial development in the state like poor infrastructure, poor marketing connectivity, political instability, shortage of electricity and lack proper entrepreneurs training institutes. Small scale industrial sector of the state have an incredible potential of feeding thousands of unemployed educated youths in state, if developed properly. An assist is need from centre and state, to frame such policies and programmes through which the Micro, small and medium enterprises in the state can be develop by leaps and bounds.
With the growth of this sector unemployment level will diminish automatically, which is the main anxiety in state.

\section{References}

1. Dar BA, Bhat FA (2013) Small Scale Industries in Jammu and Kashmir (J\&K) growth, Performance and Challenges. International NGO Journal 8: 38-43.

2. Islam AU (2014) Impact of Armed Conflict on Economy and Tourism: A Study of State of Jammu and Kashmir. IOSR Journal of Economics and Finance 4: 55-60.

3. Butt AK (2005) Strategizing Industrial Development in Jammu and Kashmir. New Century Publications, New Delhi.

4. Sharma BS, Mukesh S, Gayatri D (2015) Contribution of MSMEs in the reduction of Wealth \& Growth in Employment and Income. The Indian Economic Journal, Article 7: 79-88.

5. Bhat FA, Malik R (2014) Prospects and Problems of Micro, Small and Medium Enterprises in Jammu \& Kashmir. Golden Research Thoughts 3: $1-5$.

6. Mohandass S (2014) Impact of globalization on Micro, Small and Medium enterprises in India. Asia pacific journal of research 1: 165-170.

7. Onukwuli AG, Akam UG, Mary E, Onwuka EM (2014) Challenges of Small Scale Industries in Sustainable Development in Nigeria. IOSR Journal of Business and Management 16: 19-25.

8. Kumar P, Kamal (2013) Marketing Strategies of Small Scale Industries: A Review. International Journal on Arts, Management and Humanities 2: 35-38.

9. Mahapatra D (2007) Conflict and Development in Kashmir: Challenges and opportunities. Proceedings of the International Conference on Sustainable Development in Conflict Environments, Kathmandu: Centre for International Studies and Cooperation, pp: 68-77.

10. Abdullah A, Kamarulzaman Y, Farinda AG (2008) Legal Services and Marketing Limitations: A focus on SME in Malysia. International review of business research papers $4: 308-319$. 
Citation: Hamid W (2017) Growth, Challenges and Issues related to Micro, Small and Medium Enterprises (MSMEs) in Jammu and Kashmir. Bus Eco J 8: 328. doi:10.4172/2151-6219.1000328

Page 6 of 6

11. Baqual GM (2008) Entrepreneurship Development and Small Scale Industries (SSI, S). Srinagar: Kitab Mahal publisher and Distributers Kashmir.

12. Tesafa F (2014) Forward and Backward linkage Analysis of Manufacturing Industries in Amhara Region, Ethiopia. National Monthly Refereed Journal in Science \& Technology 3: 14-25.
13. Vivekanand P (2013) Trends, Opportunities \& Challenges in Small Scale and Cottage Industries in Uttar Pradesh. Asian Journal of Technology \& Management Research 3: 1-15. 